Priscilla Rodrigues Câmara ${ }^{1}$ Jefferson Ferreira dos Santos ${ }^{2}$ Maria Carolina de Lima Jacy Monteiro ${ }^{1}$

Rafaela Elvira Rozza de Menezes ${ }^{1}$

Adriele Ferreira Gouvêa ${ }^{1}$ Karla Bianca Fernandes da Costa Fontes ${ }^{1}$ Rebeca Souza Azevedo ${ }^{1}$ Renata Tucci ${ }^{1}$

\footnotetext{
${ }^{1}$ Universidade Federal Fluminense - UFF, Dental School, Department of Stomatology and Oral Pathology, Nova Friburgo, RJ, Brazil. ${ }^{2}$ Hospital Municipal Moacyr Rodrigues do Carmo, Duque de Caxias, RJ, Brazil.
}

Correspondence to:

Universidade Federal Fluminense, Instituto de Saúde de Nova Friburgo.

Rua Doutor Silvio Henrique Braune, 22, Centro. CEP: 28625-650. Nova Friburgo/RJ Brasil. E-mail: rtucci@id.uff.br

Article received on March 30, 2017. Article accepted on May 11, 2017.

DOI: 10.5935/2525-5711.20170009

\section{Osteocartilaginous choristoma of the tongue: a case report and review of the literature}

\section{Abstract:}

The purpose of the present article was to report a clinical case of a 53-year-old male patient with a tongue osteocartilaginous choristoma. Additionally, we made a brief review of the literature to identify all cases reported in English-language literature of oral osteocartilaginous choristoma and, to the best of our knowledge, there are only nine reported cases. Choristoma is a lesion characterized by the development of a histologically normal tissue in an abnormal site. Occurrence of osseous or cartilaginous choristomas in oral soft tissues are rather uncommon. Cases presenting both bone and cartilage simultaneously, named osteocartilaginous choristomas, are even rarer. After the literature search, we also compare the pathogenesis, clinical and histopathological features of our osteocartilaginous choristoma with the literature about osseous or cartilaginous choristomas. The present case report contributes with an additional case of osteocartilaginous choristoma of the tongue, which is suggestive of metaplasia, and it had an unusual histopathological aspect with cartilage structure as principal component. Keywords: Choristoma; Diagnosis, Oral; Pathology. 


\section{INTRODUCTION}

Choristoma is a term used to describe a nonneoplastic growth of a histologically normal tissue in an abnormal site ${ }^{1,2}$. Oral cavity can develop choristomas from different tissues, such as salivary, sweat, sebaceous and thyroid glands, cartilage, bone, glia, adipocytes and gastric mucosa ${ }^{1,3}$.

Osteocartilaginous choristoma is a well-defined swelling containing both osseous and cartilaginous tissues $^{4}$. In the oral cavity, it is extremely rare with only nine cases reported in the English-language literature. At this site, these lesions especially involve the dorsum of the tongue in women from the $5^{\text {th }}$ decade of life ${ }^{4}$. Etiology remains uncertain ${ }^{5}$ and histopathology is characterized by a mass of osseous and cartilaginous tissues. ${ }^{4}$. Management is based on complete surgical resection ${ }^{6}$.

Herein, considering its rarity, the purpose of this article is to report an additional case of an oral osteocartilaginous choristoma and to present a brief review of the literature on its pathogenesis, clinical and histopathology features.

\section{CASE REPORT}

A 53-year-old man was referred to Hospital Municipal Moacyr Rodrigues do Carmo, Duque de Caxias, Rio de Janeiro, Brazil. He complained about a swelling on the dorsum of the tongue lasting 1 year. Intraoral examination revealed an asymptomatic, normochromic, pedunculated, oval and firm nodule, measuring 1.7 in diameter. It was located in front of circumvallate papillae on the dorsum of tongue (Figure 1). The patient reported to frequently bite the lesion. Considering fibrous hyperplasia as the clinical diagnosis, an excisional biopsy was performed under local anesthesia. Sample as sent to Laboratório de Patologia Oral, Instituto de Saúde de Nova Friburgo, Universidade Federal Fluminense, Rio de Janeiro, Brazil, for histopathological analysis.

Gross specimen was solid, oval, well circumscribed, white and measured 1.5 in diameter (Figure 2). Microscopic examination revealed the presence of a parakeratinized squamous stratified lining epithelium. The lesion was separated from the overlying epithelium by a fibrous and collagenous zone (Figure 3). It had a peripheral area of cartilage with different degrees of maturation and a central area of bone (Figure 4). It was also observed the presence of chondroblasts

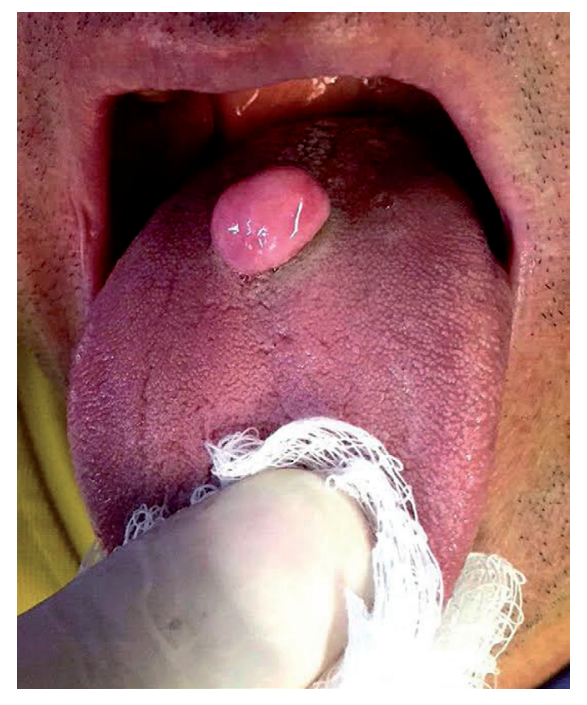

Figure 1. Normochromic nodule on the midline dorsum of posterior tongue.

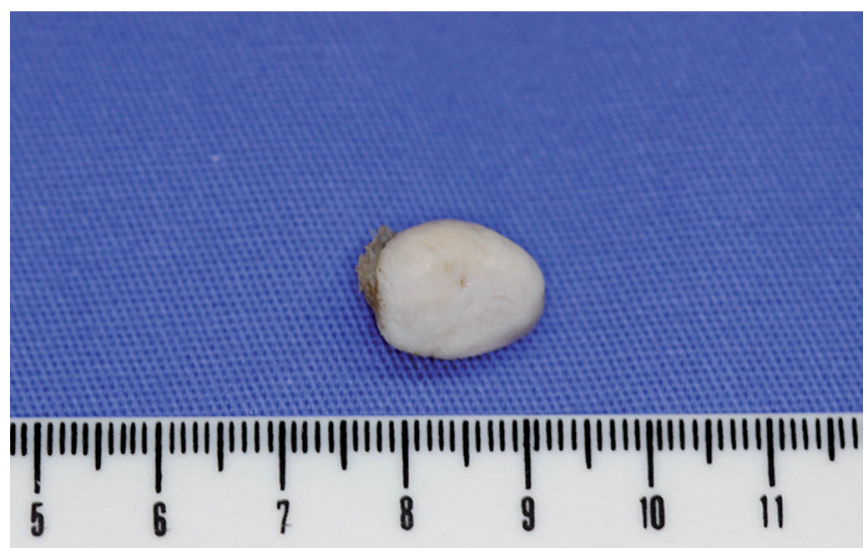

Figure 2. Oval, white and well circumscribed gross specimen.

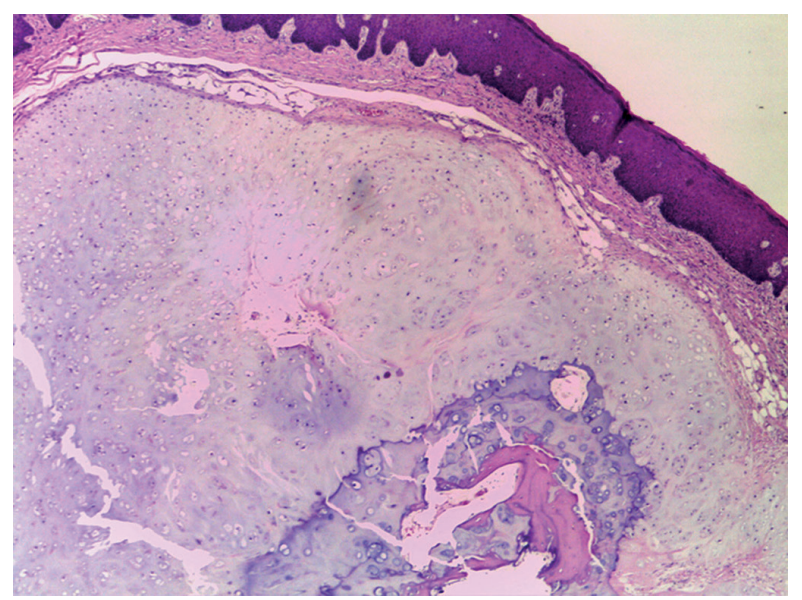

Figure 3. The lesion was separated from the overlying epithelium by a fibrous and collagenous zone (arrow). It is possible to see a proliferation of cartilage with different degrees of maturation (Hematoxylin and eosin stain, X100). 


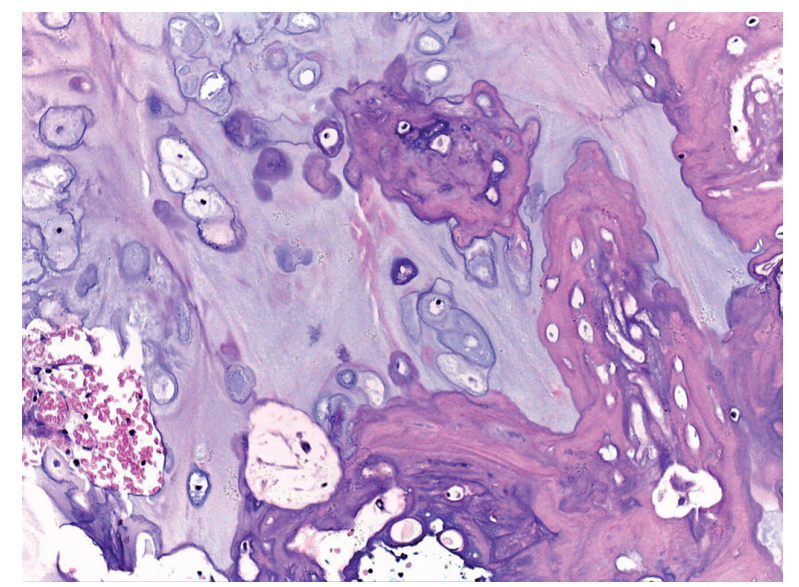

Figure 4. Cartilage with different degrees of maturation at periphery and mature bone at the central (Hematoxylin and eosin stain, X200).

and chondrocytes (Figure 5), as well as trabecular bone interspersed with blood vessels and discrete inflammatory infiltrate composed mainly of lymphocytes and plasma cells.

\section{DISCUSSION}

Proliferation of bone and cartilage in the soft tissues are uncommon findings. Proliferation of both bone and cartilage in the same lesion is extremely rare. In a review of the English-language literature, we found nine osteocartilaginous choristomas, totaling ten cases with the present report (Table 1). In this review, the age at diagnosis ranges widely from 20 to 67 years, with mean of 44.1 years. Most cases affect female (70\%), and the tongue was greatly affected $(90 \%)$, with the posterior region of the dorsum near to the foramen cecum quite commonly observed. Duration of the lesions are huge variable from months to 57 years, an entire life $e^{4,7-14}$.

Regarding to the sex, literature highlight that oral osseous choristomas tend to be more prevalent in women ${ }^{4,12}$, while cartilaginous and osteocartilaginous choristomas would affect women and men equally ${ }^{12}$. The ten oral osteocartilaginous choristomas verified a higher women prevalence, as described for osseous choristomas.

About the site of occurrence in the oral cavity, osseous choristomas are frequently located in dorsum of the tongue, posterior to circumvallate papillae or close to foramen cecum $^{13,15}$, while cartilaginous choristomas are mainly found in both anterior and posterior dorsum of the tongue, as well the lateral border of the tongue ${ }^{3,16}$. Nevertheless, according to Watson et al. ${ }^{12}$, oral osteocartilaginous choristomas

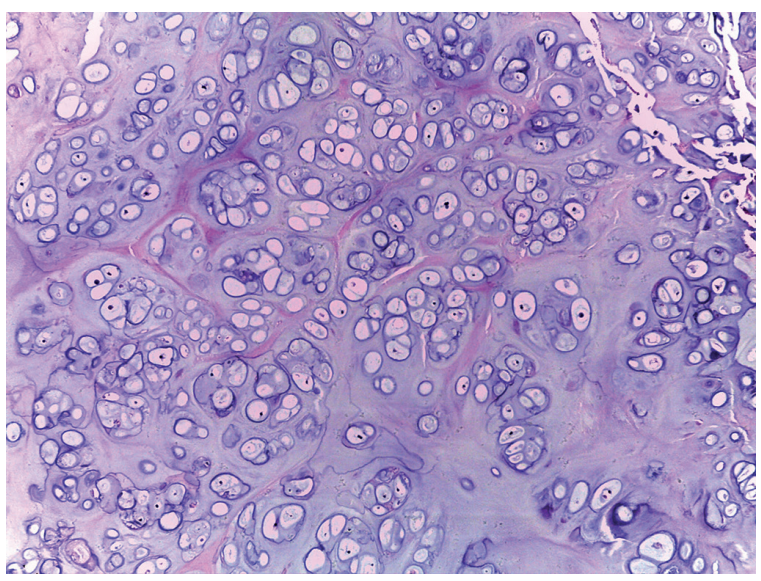

Figure 5. Areas of normal chondroid tissue (Hematoxylin and eosin stain, X200).

Table 1. Cases of osteocartilaginous choristomas reported in the English-language literature.

\begin{tabular}{|c|c|c|c|c|c|}
\hline $\mathrm{N}$ & Authors & Age & Sex & Site & Evolution \\
\hline 1 & $\begin{array}{c}\text { Roy } \\
\text { et al. } \\
(1970)^{7}\end{array}$ & 20 & $F$ & $\begin{array}{l}\text { Near to foramen } \\
\text { cecum }\end{array}$ & 10 years \\
\hline 2 & $\begin{array}{l}\text { Gabriele } \\
\text { and } \\
\text { Kaufman } \\
(1978)^{8}\end{array}$ & 22 & $\mathrm{~F}$ & $\begin{array}{l}\text { Anterolateral to } \\
\text { foramen cecum }\end{array}$ & Not described \\
\hline 3 & $\begin{array}{l}\text { Wesley } \\
\text { and } \\
\text { Zielinsk } \\
(1978)^{9}\end{array}$ & 57 & $\mathrm{~F}$ & $\begin{array}{l}\text { Ventral surface of } \\
\text { the tongue }\end{array}$ & 57 years \\
\hline 4 & $\begin{array}{l}\text { Shimono } \\
\text { et al. } \\
1984^{10}\end{array}$ & 47 & M & $\begin{array}{l}\text { Dorsal surface of the } \\
\text { tongue base }\end{array}$ & 1 year \\
\hline 5 & $\begin{array}{l}\text { Landini } \\
\text { et al. } \\
(1989)^{11}\end{array}$ & 35 & $\mathrm{~F}$ & $\begin{array}{l}\text { Left lateral border of } \\
\text { tongue }\end{array}$ & 23 years \\
\hline 6 & $\begin{array}{l}\text { Watson } \\
\text { et al. } \\
(1990)^{12}\end{array}$ & 67 & $\mathrm{~F}$ & $\begin{array}{l}\text { Junction of the an- } \\
\text { terior two thirds with } \\
\text { the posterior third } \\
\text { (midline) }\end{array}$ & 6 months \\
\hline 7 & $\begin{array}{l}\text { Piattelli } \\
\text { et al. } \\
2000^{13}\end{array}$ & 64 & $\mathrm{~F}$ & $\begin{array}{l}\text { Right ventral surface } \\
\text { of the tongue }\end{array}$ & 2 years \\
\hline 8 & $\begin{array}{l}\text { Dermise- } \\
\text { ren et al. } \\
(2007)^{14}\end{array}$ & 28 & M & $\begin{array}{l}\text { Dorsum of the ton- } \\
\text { gue, in front of the } \\
\text { foramen cecum }\end{array}$ & 4 years \\
\hline 9 & $\begin{array}{l}\text { Venugo- } \\
\text { pal et al. } \\
(2014)^{4}\end{array}$ & 48 & $\mathrm{~F}$ & Left Buccal mucosa & 4 months \\
\hline 10 & $\begin{array}{l}\text { Present } \\
\text { case }\end{array}$ & 53 & M & $\begin{array}{l}\text { Dorsum of the ton- } \\
\text { gue, posterior region } \\
\text { near the circumvalla- } \\
\text { te papillae }\end{array}$ & 1 year \\
\hline
\end{tabular}


would be confined to the foramen cecum. This review actually revealed a greater predilection for the foramen cecum region, however the lesions were not confined to this area, and may occur at other locations, such as ventral portion or lateral border of tongue, and also the one case involving the buccal mucosa ${ }^{15}$.

It is important to note that choristoma pathogenesis is still uncertain, then, it is widely discussed in the literature. Overall, considering the tongue as the main oral osteocartilaginous choristoma location, there are five theories to explain its histogenesis ${ }^{5}$, including: metaplasia; proliferation of cartilaginous embryonic rests; pluripotential cell derivation; mixed tumor with preponderance of cartilage; neoplasms or teratomas with preponderance of cartilage.

In this way, it is believed that the main theory for osteocartilaginous choristomas histogenesis is metaplasia, since, in fact, some reported cases are preceded by a history of trauma ${ }^{5}$. Presence of trauma would lead to a chronic inflammation that stimulate the metaplastic formation based on the transformation of mesenchymal cells into chondrocytes, and, as a consequence, in the oral cavity, the lesion would be more frequently located on the dorsum and anterior region of the tongue, or on the lateral border of tongue ${ }^{3}$. Reinforcing this theory, in the present case, the patient reported that has the use of biting the region where the lesion was located. In addition, in the histopathology, it was possible to observe chronic inflammatory cells.

Other theory widely accepted, mainly because many choristomas, especially the osseous type, and even the osteocartilaginous type, are in the posterior region of tongue, near the foramen cecum, is the proliferation of embryonic rests. This theory postulated that the osteocartilaginous lingual lesions originate from heterotopic cartilage remnants left in the tongue, which could be displaced from any of the first four branchial arches that give rise to this organ during embryonic development $t^{3,5}$.

Another possibility for cartilage origin in this cases is the remnants of Meckel's cartilage, which form the mandibular arch and also contributes to tongue development ${ }^{11,16}$. However, in contrast to embryonic rests theory, a study performed by Van Der Wal and Van Der Waal ${ }^{15}$ did not found neither bone or cartilage in the tongue of 130 cadavers, thus, turning it unlikely the possible origin of cartilaginous embryonic rests in cartilaginous or osteocartilaginous choristoma ${ }^{6}$.
Clinically, oral choristomas are observed as a firm, nodular pedunculated or sessile swelling, ranging from 0.5 to $2 \mathrm{~cm}$ in diameter. Most patients are unaware of the lesion, but symptoms of pain, dysphagia, gagging, choking, and nausea have been reported ${ }^{17}$. Since the intraoral choristoma is rare, most of them are clinically misdiagnosed as other soft tissue tumors ${ }^{17}$. Main differential diagnosis for intraoral choristomas are fibrous hyperplasia, pyogenic granuloma, a cyst, a salivary gland tumor and an ectopic thyroid tissue ${ }^{14,15,17}$.

On histopathology, oral choristomas are composed by a well-circumscribed mass that can present variable lamellar bone with well-developed havers system (osseous choristoma), a well-developed viable mature cartilage mass (cartilaginous choristoma), or a combination of bone and cartilage surrounded by a fibrous connective tissue (osteocartilaginous choristoma). Occasionally, hematopoietic cells or fatty marrow has been reported in osseous lesions. Osteoblastic or osteoclastic activity are rarely seen ${ }^{4,17}$.

In the present case reported, it was observed a fibrous connective tissue zone separating the lesion from the epithelium surface. According to Sasaki et al. ${ }^{6}$, this area would be suggestive of a perichondrium. The lesion was then mainly composed of cartilage with different degrees of maturation, being a more mature tissue in the center and a less mature tissue in the periphery. At the central portion, mature bone tissue was observed, however, as noted, the most predominant component of the lesion was cartilage. Based on these findings, we speculate that this central bone may correspond to an early maturation process of cartilage, as described by Demirseren et al. ${ }^{14}$.

Furthermore, it is important to emphasize that it was not observed the presence of atypia, infiltration of adjacent tissues, and the presence of salivary gland tissue, then discarding the possibility of malignant neoplastic lesions or glandular origin.

Choristoma treatment is based on the complete surgical excision of the lesion and recurrence has not been reported, such as in our case $e^{6,17}$.

\section{CONCLUSION}

Oral choristomas are rare, being osteocartilaginous choristomas even rarer. Development of these osteocartilaginous lesions may reflect a metaplastic origin, especially in cases with previous local trauma. 
Most of the studies describes an osteocartilaginous lesions with predominant component of bone or else a balance between bone and cartilage components, however in this case, was observed a principal cartilage component and a bone component only in the central portion of the lesion. Therefore, this article then contributes with an additional case of a rarely lesion and presents its most probable pathogenesis and its differentiated histopathology.

\section{REFERENCES}

1. Chou LS, Hansen LS, Daniels TE. Choristomas of the oral cavity: a review. Oral Surg Oral Med Oral Pathol. 1991;72:58493.

2. Gorini E, Mullace M, Migliorini L, Mevio E. Osseous choristoma of the tongue: a review of etiopathogenesis. Case Rep Otolaryngol. 2014;2014:373104.

3. Desmedt M, Weynand B, Reychler H. Cartilaginous choristoma of the oral cavity: a report of two cases. B-ENT. 2007;3:87-91.

4. Venugopal R, Bavle RM, Mallar KB, Rakesh P. Osteocartilaginous choristoma of buccal mucosa: A rare entity. J Oral Maxillofac Pathol. 2014;18:478-80.

5. Mosqueda-Taylor A, González-Guevara M, de la PiedraGarza JM, Díaz-Franco MA, Toscano-García I, Cruz-León A. Cartilaginous choristomas of the tongue: review of the literature and report of three cases. J Oral Pathol Med. 1998;27:283-6.
6. Sasaki R, Yamamoto T, Okamoto T, Ando T. Cartilaginous choristoma of the tongue. J Oral Maxillofac Surg Med Pathol. 2015;27:295-8.

7. Roy JJ, Klein HZ, Tipton DL. Osteochondroma of the tongue. Arch Pathol. 1970;89:565-8.

8. Gabriele R, Kaufman PS. Osteochondroma of the tongue: report of case. J Oral Surg. 1978;36:476-7.

9. Wesley RK, Zielinski RJ. Osteocartilaginous choristoma of the tongue: clinical and histopathologic considerations. J Oral Surg. 1978;36:59-61.

10. Shimono M, Tsuji T, Iguchi Y, Yamamura T, Ogasawara M, Honda T, et al. Lingual osseous choristoma. Report of 2 cases. Int J Oral Surg. 1984;13:355-9.

11. Landini G, Kitano M, Urago A, Sugihara K, Yamashita S. Chondroma and osteochondroma of the tongue. Oral Surg Oral Med Oral Pathol. 1989;68:206-9.

12. Watson C, Crowther JA, Stephen MR. Osteochondroma of the tongue. J Laryngol Otol. 1990;104:138-40.

13. Piattelli A, Fioroni M, Orsini G, Rubini C. Osteochondromatous choristoma of the tongue: report of a case. J Oral Maxillofac Surg. 2000;58:1320-2.

14. Demirseren ME, Aydin NE. A lingual osteoid mass originating from hyaline cartilage. J Craniomaxillofac Surg. 2007;35:132-4.

15. van der Wal N, van der Waal I. Osteoma or chondroma of the tongue; a clinical and postmortem study. Int J Oral Maxillofac Surg. 1987;16:713-7.

16. West CB Jr, Atkins JS Jr. Choristomas of the intraoral soft tissues. Otolaryngol Head Neck Surg. 1988;99:528-30.

17. Tohill MJ, Green JG, Cohen DM. Intraoral osseous and cartilaginous choristomas: report of three cases and review of the literature. Oral Surg Oral Med Oral Pathol. 1987;63:506-10. 